XXXV.-List of Coleoptera received from Old Calabar, on the West Coast of Africa. By Andrew Murray, Edinburgh.

[Continued from vol. i. ser. 3. p. 135.]

\title{
Chlæniidæ (continued).
}

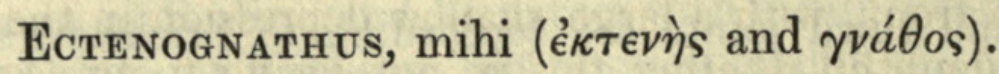

Mentum dente medio simplice. Palpi tenues, elongati et subcylindrici (articulis ultimis adhuc ignotis). Mandibuli valde projicientes, elongati, fortiter arcuati et apice acutissimo. Maxillæ spinis paucis armatæ. Labrum subquadratum, postice parum angustatum, levissime emarginatum. Antennæ filiformes, articulo tertio cæteris longiore. Prothorax subcordatus, antice emarginatus, postice truncatus, margine reflexo. Elytra prothorace latiora, quadrato-ovalia, parum convexa. Tarsi marium ignoti, fœminarum ut in cæteris generibus Chlaniidarum.

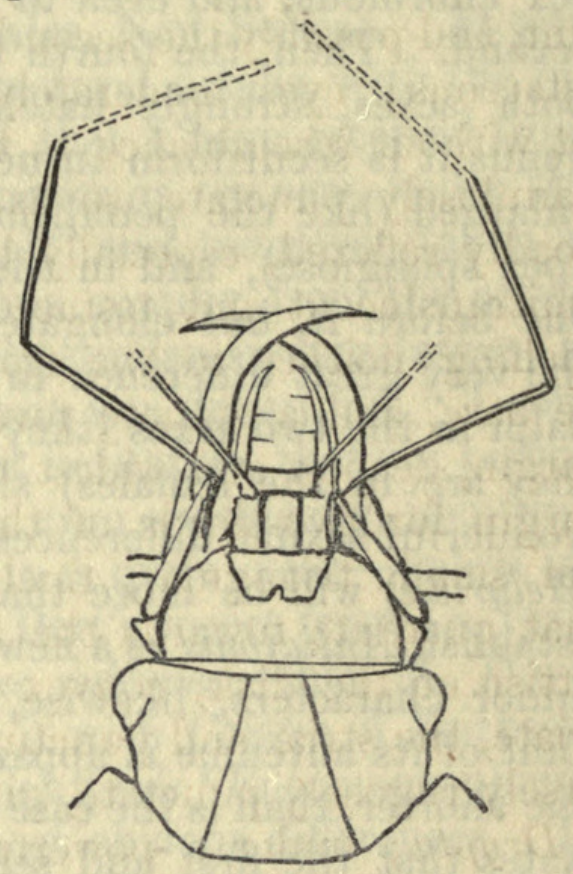

1. E. Dryptoides, mihi.

Supra nigro-virens et satis opacus, subtus niger et politus; capite antice, ore, gula, suturæ apice et pedibus testaceis; capite postice leviter granuloso, antice impunctato; thorace fortiter et dense punctato, margine late et profunde reflexo; elytris opacis, leviter punctato-striatis, interstitiis transversim papillose punctatis atque transversim levissime aciculatis; subtus prosterno leviter punctato, mesosterno et metasterno fortiter punctatis.

Long. $6 \frac{1}{2}$ lin., lat. $2 \frac{1}{2}$ lin.

Rather narrow; greenish black and opake above, black and polished below ; the anterior part of the head, the basal joint of the antennæ, the parts of the mouth, the throat, the extreme margins of the sides of the thorax, the reflexed margin of the elytra, particularly towards the apex, and a narrow margin on their sides and suture near their apex, and the legs, testaceous. Head finely granulose behind, smoother on the vertex, which is somewhat raised; front smooth and impunctate, with a transverse shallow depression in the middle opposite the anterior part of the eyes, an irregular depression and some granulose punctures on each side close to the base of the antennæ; the 
greenish colour of the head advances in the centre as far forward as the front of the eyes, but the testaceous colour passes backward on each side as far as the middle of the eye; the apex of the mandibles and of the joints of the palpi is darker than the rest; clypeus rather broad; labrum quadrate, somewhat broadest in front, with a large shallow depression in the centre (but I am doubtful whether this is not owing to an accidental crushing in my specimen); antennæ dark fuscous, the basal joint, and possibly the second, which is the shortest, more or less testaceous; eyes moderately prominent. Thorax subcordate, not without resemblance to the thorax in Agonum, coarsely and granulosely punctate, so as to appear opake; margins rather broadly reflexed, especially behind, with their edges narrowly semitranslucent and testaceous; dorsal line well marked, but reaching neither to the front nor back; a depression across the base, and a sinuate fovea on each side within the reflexed margin, deepest and widest behind, following the outline of the margin for two-thirds of the length of the thorax. Scutellum small, triangular, finely granulose, elongate-oval, somewhat quadrate towards the shoulders and apex. Elytra opake, flattish on the disk, convex on the sides and apex, punctatestriate, the striæ and punctures fine; the interstices flat, transversely rugosely punctate, giving the appearance of the elytra in Drypta ; under a powerful lens, the rugosity of the punctation is seen to be caused by the punctures having been made as it were from behind, so that in front of each there is a slight papillose elevation : besides this punctation, there is a very fine transverse aciculation; and there is a fine short pubescence proceeding from the punctures along the sides, which probably in fresh examples will extend over the whole elytra; the scutellar stria extends nearly a fourth of the length of the elytra, and the narrow edging of testaceous along the suture at the apex, which scarcely goes beyond the first stria, extends forwards about the same length. Under side polished, shining; prosternum very sparingly and faintly punctate; mesosternum and metasternum roughly and rather closely punctate; segments of abdomen faintly rugose, particularly at the sides.

I have only received a single specimen of this interesting species, and, unfortunately, the last joints both of the palpi and antennæ are wanting; but there remain sufficient characters of generic importance to enable me to allot it a place as a new genus of the Chlaniida.

Oodes, Bon.

1. O. obesus, mihi.

Latus, convexus, niger, subnitidus, impunctatus, lævis ; antennis 
palpisque piceis ; mandibulis piceis, planis, margine exteriore reflexo; thorace marginibus (præcipue antice) depressis, linea sublaterali arcuata; elytris punctato-striatis, interstitiis convexis ; tarsis piceis, anticis pallidioribus. Long $5 \frac{1}{2}$ lin., lat. $3 \frac{1}{2}$ lin.

Broad and convex; black, smooth, and impunctate, with a dull, somewhat silky lustre, occasioned by a very fine aciculated punctation, scarcely visible except under the compound microscope. Head smooth, with a slight depression along the front, and with two small pits between the eyes ; middle tooth of the mentum with a tendency to become bifid; antennæ piceous, first three joints shining, the rest pubescent and more dusky ; palpi piceous; mandibles piceous, flat, rather thin, circular exteriorly, straight interiorly, except at the point, which has a rounded tooth; exterior margin slightly raised and reflexed posteriorly; clypeus slightly emarginate, with a deep square depression in the middle of the anterior margin, and two large foveæ in each of the anterior angles. Thorax convex, without marginal line, except a very faint one on each side in front, with a linear depression from each anterior angle reaching almost to the basal margin, curved inwards, deepest in front, and leaving a broad marginal space widest behind: the appearance of this line reminds one of a bridle lying on the neck of a horse; it is, however, very faintly recurved near the base : dorsal line faint, reaching neither to the anterior nor basal margins. Scutellum large. Elytra punctate-striate; interstices convex; the short scutellar stria along with the sutural stria converging to meet the third and fourth striæ at the base; the second stria straight; the striæ deepest towards the apex, which is slightly sinuate. Under side with the episterna and sides of the metasternum punctate; sides of abdomen slightly punctate; the prosternum slightly prolonged behind, with the prolongation margined. Tibiæ short; anterior tibiæ broad and triangular; anterior tarsi piceous, in the male with the first three joints very broad and transverse, and the fourth very small.

The most striking character in this species is the form of the mandibles and the projecting prosternum; the former might perhaps justify its establishment as a subgenus, and the latter would seem to approach it to the genus Lonchosternus of Laferté, of which the only character differentiating it from Oodes is the prosternum prolonged as in Hydrophilus. The projection here has no pretensions to such an extensive prolongation, but it may be viewed as the passage leading to it. The species is readily recognized by these characters, and by the bridle-shaped depression on the thorax. 


\section{O. politus, mihi.}

Niger, nitidus, impunctatus, politus ; antennis fuscis, ad basin ferrugineis ; mandibulis ferrugineis, acutis, supra haud convexis; capite et thorace lævissimis, hoc stria marginali tenui laterali et anteriori; elytris politis, leviter striato-punctatis, interstitiis planis, spatio marginali opaco, ad apicem latiore.

Long. $4 \frac{1}{2}$ lin., lat. 3 lin.

Black, shining, impunctate, and polished. Head smooth, with scarcely any depressions; antennæ with the first three joints ferruginous, rest dusky; palpi piceous ; terminal joint of maxillary palpi elongate and ovato-cylindric (rest wanting in my specimen); mandibles ferruginous, darker at tip, not convex, triangular, making the muzzle sharp, nearly straight on the outer side, slightly curved and without teeth on the inner; clypeus large, transverse, scarcely emarginate; mentum with a strong middle tooth, and the lateral lobes large, acute, and with a conical outline; ligula as in the rest of the Chlaniida, free at its extremity, and cut straight. Thorax smooth, convex, and with a faint thin stria along the lateral and anterior margins, none on the basal. Scutellum rather large. Elytra delicately punctate-striate ; interstices flat and shining; the scutellar stria along with the first and second converging at the base to meet the fourth, the third straight; a marked opake and rugose marginal space surrounding the sides and apex of the elytra, widest at the apex; the margin of the rest of the elytra touching this space sharply defined, so that the polished disk seems to lie on the top of an under opake layer; the apex slightly sinuate. Under side with scattered punctures, except along the middle; the prosternum somewhat projecting and slightly grooved, as in last species. Legs piceous (the anterior legs are wanting in my specimen).

I have only received one imperfect specimen of this species; and the want of its anterior legs, combined with the somewhat different form of the mentum and terminal joint of the palpi, prevent me referring it with absolute certainty to this family; but I have no doubt, from its general facies, taken along with the other characters which remain, that $I$ have placed it correctly.

\section{Cratoceridæ.}

\section{Diatypus, mihi.}

(From $\delta\llcorner a \tau v \pi o \omega$, alluding to its being the representative in Africa of the genera Daptus, Geopinus, Agonoderus, \&c.)

Mentum breve, profunde emarginatum, dente medio curto et obtuso, lobis lateralibus latis, fortiter extus rotundatis. Ligula parva, ad basin coarctata, ad apicem truncata. Paraglossæ 
dilatatæ, rotundatæ. Articulus ultimus palporum maxillarium ad basin cylindricus, in medio tumidus, ad apicem acuminatus ; articulus ultimus palporum labialium similis, sed minus tumidus et minus acuminatus et truncatus. Mandibuli fortes, densi, dexter intus bidenticulatus, sinister unidenticulatus. Labrum quadratum. Caput mediocre, haud retro coarctatum. Oculi satis prominentes. Antennæ ad instar capitis et prothoracis longitudine ; articuli primus, tertius et quartus longitudine æquales, cæteris longiores, et, cum secundo (breviore), obconici, quintus et sequentes parum depressi. Prothorax subquadratus, parum retro coarctatus; anguli antice rotundati, postice distincti. Elytra prothorace paullo latiora, parum elongata, parallela, ad apicem sinuata. Pedes mediocres : tibiæ anteriores parum dilatatæ et versus apicem extus denticulatæ; tibiæ intermediæ et posteriores haud denticulatæ; tarsi subtus fortiter ciliati, anteriores et intermedii maribus dilatati, articulis quatuor primis triangularibus, primo longiore, quarto bilobato in omnibus tarsis, posterioribus haud dilatatis. Corpus satis elongatum.

In general appearance the species composing this genus approach nearer to the American genus Geopinus than to any other which I have seen, but are readily distinguished from it by the possession of a median tooth to the mentum, besides the other characters above mentioned; their form also is less convex, and approaches more nearly to Anisodactylus. The place of the genus seems to be next to Dejean's and Schmidt-Goebel's Indian genus Batoscelis, as defined by Lacordaire, from which it differs in the following respects:-its mentum is deeply, instead of being feebly emarginate; its ligula is small, instead of being "assez grande;" its paraglossæ are rounded instead of being. truncate, and can scarcely be called arched. In other respects the characters seem almost the same. The bilobed fourth joint of the tarsi is not noticed in Lacordaire's description. Probably it would have been better for me to have widened the characters of the genus Batoscelis, so as to have admitted the following species, instead of making a new genus for them; but the difference of their native country has induced me to separate them.

\section{D. Dohrnii, mihi.}

Fusco-virescens; antennis, clypeo, mandibulis palpisque ferrugineis ; capite polito, foveis duabus inter oculos linea antica transversa junctis; thorace leviter marginato, lateribus depressis, angulis posticis foveolatis, disco leviter, lateribus fortius punctato; scutello impresso; elytris levissime punctatis, striatis, striis impunctatis, interstitiis leviter convexis ; subtus 
fuscus, lateribus (episternis et epimeris) leviter et irregulariter punctatis, medio et abdomine impunctatis; pedibus pallidis. Long. 5 lin., lat. $2 \frac{1}{4}$ lin.

Above fuscous with a virescent tinge. Head polished and sparingly punctate behind the eyes, the rest impunctate, or nearly so ; a deep angular fovea on each side near the inner corner of the eyes, united by a deep impunctate transverse line, in front of which the epistome is marked by a broad, transverse, somewhat rugose depression; antennæ, clypeus, palpi, and parts of the mouth more or less ferruginous; clypeus with a row of depressions in front, from each of which springs a hair. Thorax rather convex, with a broad well-defined depression along the margins and angles, broadest at the posterior angles, and bordered all round with a slight raised edging; slightly punctate on the disk, more deeply so on the depressed margins; the dorsal line is feebly punctate-striate, and reaches only to the anterior semilunar depression, which is well marked; the base is very slightly but broadly emarginate; in front of the emargination is a sinuate transverse depression, on each side of which is a fovea ; the anterior angles are broadly rounded, the posterior are obtuse. Scutellum ferrugineo-fuscous, rugosely impressed. Elytra with a greater virescence than the head and thorax, very faintly punctate; striate, but without punctation in the striæ; the interstices slightly convex; two or three slight fover on the outer side of the second stria, one about a third from the base, the next about a third from the apex, and the last about a sixth from the apex; a number of pits are placed at irregular distances along the marginal space. Under side fuscous, paler than above, and not virescent; the middle and the abdomen are not punctate, but the side-pieces (episterna and epimera) are all faintly and irregularly punctate. The legs are pale testaceous.

I have named this species after Herr Dohrn of Stettin, an entomologist of world-wide reputation, whose great attainments as a man of science are only equalled by his genial and endearing qualities as a friend.

\section{D. Smithii, mihi.}

Præcedenti similis, sed major ; niger et haud virescens ; capite linea transversa antice multo minus profunda; thorace disco impunctato, angulis posticis minus obtusis, ad mucronem fere rectis ; elytris interstitiis impunctatis, striis profundioribus quam in D. Dohrnii; subtus vix punctatus ; cæteris ut in D. Dohrnii.

Long. 6 lin., lat. $2 \frac{1}{2}$ lin.

Closely allied to the preceding, but differs from it in the fol- 
lowing particulars. It is black instead of virescent fuscous. The head is wholly impunctate; the angular depressions in front are shallow, and united by a faint transverse line instead of a deep groove, and the epistome has scarcely any depression. The thorax is impunctate on the disk; the dorsal line is scarcely punctate, and it reaches wholly to the front, the posterior angles are less obtuse than in D. Dohrnii, and somewhat sinuate, so as at the very point to be almost right-angled for a short space. The elytra are more deeply striate, and the interstices more convex and impunctate. The under side has scarcely any punctation at all, either on the sides or middle. In other respects the same description will apply to the two species.

I have named this species after my friend Mr. Frederick Smith of the British Museum, whose kindness places the extensive information he possesses at the disposal of all who desire to profit by it.

\section{Anisodactylidæ.}

\section{Orthogonius, Dej.*}

\section{O. rugiceps, mihi.}

Latus, depressus, niger, subnitidus ; antennis, palpis, abdomine tarsisque piceis ; capite punctato-rugoso, bi-impresso ; thorace leviter et sparsim transversim rugoso, interstitiis levissime et perparce punctato, sine punctis majoribus in rugis; elytris lepidissime et subtilissime transversim aciculatis, striato-punctatis, interstitiis parum convexis, hic et illic leviter punctatis ; subtus subopacus; abdomine subtiliter aciculato, præcipue lateribus.

Long. 8 lin., lat. $3 \frac{1}{3}$ lin.

Depressed, broad, black, with something of a silky gloss. Head rugosely punctate, with two longitudinal depressions between the antennæ united by a transverse line; antennæ, palpi, and parts of the mouth piceous. Thorax transversely rugose, lightly and sparsely on the disk, more coarsely on the depressed sides and base, the spaces between the rugosities on the disk faintly and sparingly punctate, no larger punctures in the rugæ;

* Notwithstanding the high authority of M. Lacordaire, to which I have deferred for the sake of uniformity, I cannot bring myself to think that this is the proper position of this genus. Sometimes trifling distinctions, which are yet found constant in a group, help one to discover the true affinities of a species when more prominent characters fail. In this instance the pectination of the claws of the tarsi, the acicular microscopic sculpture on the elytra, along with their truncation, lead me to look for the proper place of the genus in the neighbourhood of Calathus, Pristonychus, \&c., in which exactly the same characters are found. 
a triangular fovea on each side of the base united by a somewhat bisinuate transverse line; dorsal line distinct, reaching from this basal line to the anterior margin; semilunar depression in front distinct and somewhat triangular, not more punctate or rugose than the neighbouring parts; posterior angles obtuse, not rounded, approaching a right angle at the very point for a very short space. Scutellum rather elongate, impunctate. Elytra broader than the thorax, two and a half times the length of the thorax; shoulders prominent, marked with the finest transverse aciculations, which are not visible except under a powerful magnifying glass; punctate-striate; the interstices sparingly and faintly punctate here and there; slightly convex, wider at the base than the apex, the space between the third and fourth and fifth and sixth striæ widest, the latter with a rugose marking at the base ; the marginal space wide, widest towards the apex. The under side of the body black, impunctate; abdomen dark piceous, with a silky opake lustre ; more strongly aciculate than the elytra. Thighs with papillary punctures along the sides and near the joint; tibiæ and tarsi dark piceous.

This species seems to come nearest to Hope's O. latus, or his O. longipennis, described in these 'Annals,' 1st series, vol. x. p. 92 ; but the somewhat larger size, and the sulcation of the elytra, instead of striation, with the deep punctation of the sulci, "sulcis fortissime punctatis," which he gives as a character of the former, sufficiently distinguish it from this species; and the relative proportions of the elytra and thorax in $O$. longipennis, the former being stated at four times the length of the latter, prevent its being confounded with this, which has the elytra only two and a half times the length of the thorax.

\section{O. Clarkii, mihi.}

Niger vel nigro-piceus, nitidus, præcedente angustior et convexior; antennis trophisque, corpore subtus pedibusque ferrugineopiceis ; capite sparsim profunde punctato, bi-impresso ut in O. rugicipite; thorace fere ut in O. rugicipite, sed lævior et cum punctis sat profundis in rugis positis ; elytris multo minus distincte aciculatis quam in O. rugicipite, minus profunde striatopunctatis, interstitiis fere planis, sparsim punctatis præcipue lateribus et apice, et cum lepidis lineis hic et illic irregulariter transversim ductis ; subtus ut in $O$. rugicipite, sed episternis metathoracicis oblique rugosis ; femoribus pallidioribus. Long. $7 \frac{1}{2}-8$ lin., lat. 3 lin.

Black or dark piceous, shining, narrower and more convex than $O$. rugiceps. Head not rugose, but covered with large, deep, scattered punctures; an angular depression united by a trans- 
verse groove between the antennæ. Thorax nearly as in $O$. rugiceps, but smoother and with a few large punctures irregularly dispersed in the wrinkles or scratches which extend irregularly over the disk, but principally in a transverse direction; the dorsal line is well marked, but does not reach to the anterior margin; posterior angles obtuse. Elytra three times the length of the thorax, broader than the thorax, but not so much so as in O. rugiceps ; much more finely aciculated than in that species, so that they are more shining and have less of a silky gloss; they are less deeply punctate-striate; the interstices almost flat, sparsely punctate, but more closely and deeply towards the sides and apex; these punctures are larger than the similar ones in O. rugiceps; there are also a number of delicate scratches or wrinkles, which extend here and there more or less transversely or obliquely across the different interstices; the space between the sixth and seventh striæ is narrowest, widening a little towards the base, and more so towards the apex; in other respects nearly as in $\boldsymbol{O}$. rugiceps. The under side is ferrugineo-piceous, the sides of the body with an occasional puncture, and the metathoracic episterna deeply wrinkled obliquely; the abdomen very finely aciculated, with two punctures on each segment in the middle and two on each side. Legs dark piceous, thighs lighter. I have named this species after my able and amiable friend, well known to all British entomologists, the Rev. Hamlet Clarke.

\section{O. pinguis, mihi.}

Latus, niger, nitidus ; antennis, trophis, corpore subtus pedibusque ferrugineo-piceis; capitis vertice et fronte profunde punctatis ; thorace ut in $O$. Clarkii, sed rugis magis reticulatis, linea dorsali profunda; scutello polito; elytris lepidissime aciculatis, leviter striato-punctatis, interstitiis fere impunctatis sed sparsim et leviter punctatis inter strias quintas et sextas, sine lineis transversis lepidis; subtus politus ; abdomine fere ut in $O$. Clarkii.

Long. $5 \frac{1}{2}$ lin., lat. $2 \frac{3}{4}$ lin.

Broader for its size than either of the two preceding species; black, shining. Head coarsely and deeply punctate on the vertex and in front, not punctate on the sides behind the eyes ; a somewhat quadrate smooth patch also in front in the centre behind the epistome; a fovea on each side in front, between which is a transverse line, which forms the anterior margin of the smooth space; in front of this line is the epistome, which is impunctate, except by four deep punctures in a transverse groove which traverses it; antennæ and parts of the mouth ferrugineo-piceous. Thorax nearly as in $O$. Clarkii, except that the wrinkles are not so 
transverse as in it, some of them running longitudinally or obliquely, so as in parts to form faint wide-meshed reticulations; the dorsal line is rather deeper, and reaches to the anterior margin. Scutellum polished. Elytra nearly three times the length of the thorax; very delicately aciculated, though scarcely so finely as in O. Clarkii ; finely punctate-striate; the interstices without the transverse scratches which occur in $O$. Clarkii; with scarcely a single faint puncture, except on the interstice between the fifth and sixth striæ; the interstices somewhat convex, especially towards the sides, where the striæ are deepest; the space between the sixth and seventh striæ narrowest, and nearly as in $O$. Clarkii, but almost without any widening at the base. Below ferrugineo-piceous; some faint scratches on the episterna, but nothing like the deep oblique wrinkles on the metathoracic episternum in O. Clarkii ; abdomen nearly as in it. Legs ferrugineo-piceous ; thighs rather paler.

This species comes near Dejean's description of O. brevithorax; but the latter is described as having the interstices on the elytra all punctate, which is certainly not the case here.

XXXVI._On Phyllangia, a new living British Madrepore. By Philip H. Gosse, F.R.S.

To the Editors of the Annals of Natural History.

\section{Gentlemen,}

With much pleasure I announce the discovery of an interesting living Madrepore, new to the European seas, if not new to science.

About six weeks ago, Mr. G. H. King, of this town, dredging in Weymouth Bay, brought up a piece of the bottom, about a foot square, evidently the edge of one of the oolite ledges, torn off by the dredge. On this were from fifty to a hundred specimens of a little Madrepore, which was considered to be our common Cyathina Smithii. The group was broken up and dispersed; but a fragment having fallen under my notice, I immediately saw in it characters which distinguished it from Cyathina.

It proves to be of the genus Phyllangia of Milne-Edwards (Hist. Nat. des Corallaires), and agrees in the most minute particulars (with one or two slight exceptions) with the $P$. americana of the same author.

The exceptions are-1st. That whereas $P$. americana is described and figured as reaching half an inch in diameter, none of the specimens procured at Weymouth attained (as I was told) quite half those dimensions, those which fell under my own notice not exceeding one-sixth of an inch. 2ndly. That whereas Ann. \& Mag. N. Hist. Ser. 3. Vol. ii. 


\section{$2 \mathrm{BHL}$ Biodiversity Heritage Library}

Murray, Andrew. 1858. "XXXV.- - List of Coleoptera received from Old Calabar, on the West Coast of Africa." The Annals and magazine of natural history; zoology, botany, and geology 2, 340-349.

View This Item Online: https://www.biodiversitylibrary.org/item/19434

Permalink: https://www.biodiversitylibrary.org/partpdf/34550

\section{Holding Institution}

Natural History Museum Library, London

\section{Sponsored by}

Natural History Museum Library, London

\section{Copyright \& Reuse}

Copyright Status: Public domain. The BHL considers that this work is no longer under copyright protection.

This document was created from content at the Biodiversity Heritage Library, the world's largest open access digital library for biodiversity literature and archives. Visit BHL at https://www.biodiversitylibrary.org. 